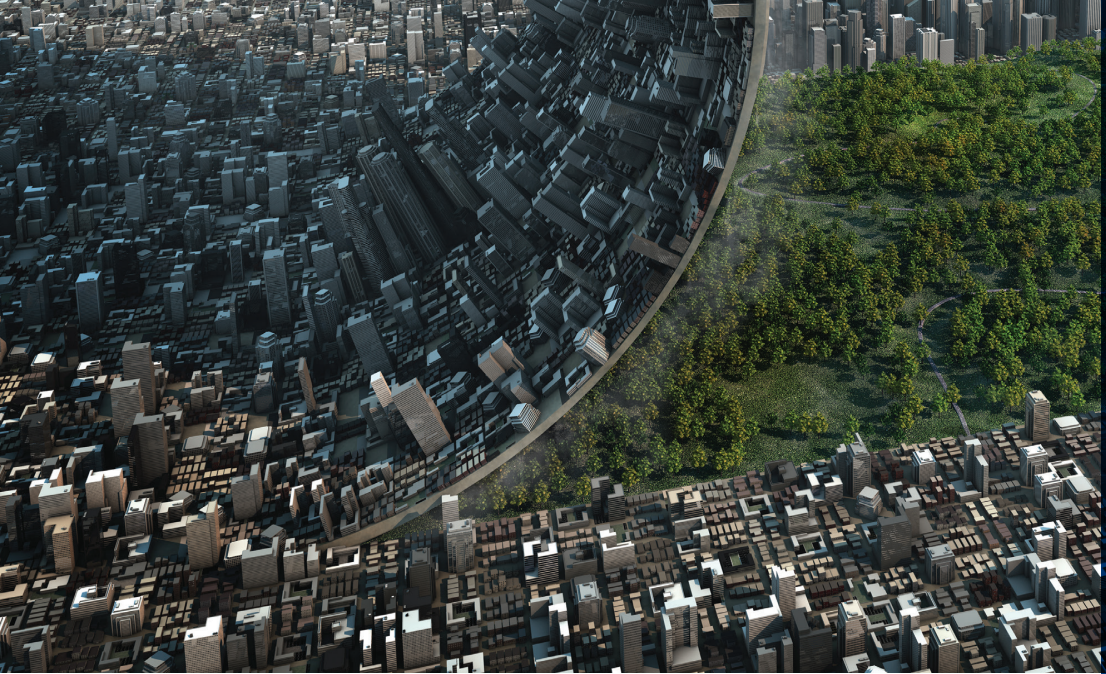
i.

\title{
BUSINESS
} AND THE ENVIRONMENT

editors

Tomasz Dorożyński

Anetta Kuna-Marszałek 


\title{
Chapter 2
}

\section{CORPORATE SOCIAL RESPONSIBILITY}

\author{
Małgorzata Misiak
}

\subsection{The notion of CSR}

Due to its relatively long history ${ }^{10}$, the idea of corporate social responsibility (CSR) has made reference to various justifications and has been interpreted in different ways. According to one of its definitions, CSR is a duty of the management to take decisions and actions that will take care both of the firm's own interests (to multiply profit) and protect and improve the well-being of people (Davis, Blomstrom 1966). The above definition stresses two aspects of social responsibility. Protecting societal well-being means enterprises should avoid actions that are harmful, even if they bring profit, and simultaneously they should undertake actions aimed at preventing and eliminating negative social phenomena that result from their operations. Maximising the well-being of people is equivalent to getting engaged in a variety of social undertakings (Rybak 2004, p. 28). We can deduce from the above that in the area of CSR there are two approaches to responsibility: a passive one, which consists in refraining from pursuing harmful activities, and an active one that mitigates and prevents negative social effects of business activities.

An enterprise:

- acts responsibly,

- bears responsibility,

- assumes responsibility,

- is held to account.

${ }^{10}$ For the first time the idea of social responsibility was formulated by Carnegie in Gospel of Wealth published in 1899. 
The first means doing business in accordance with legal and social norms. Bearing responsibility is about corporate responsibility for the effects of the firm's actions. In other words, the firm in question is ready to face the consequences of its deeds. Bearing responsibility and being held to account refer to situations that have already happened in the past. The only difference is the subject, who assesses a particular action. In the first case, it is the firm, the actual perpetrator of an act. In the second case, the assessment is external to the perpetrator although it is addressed to him and is designed to provoke specific changes in his behaviour (Klimczak 1996, p. 58).

Social responsibility is based on the stakeholder theory, according to which a firm maintains relations with a variety of actors who influence its operations but at the same time are influenced by it. ${ }^{11}$ Enterprises operate in an environment where the effects of corporate activities are felt and experienced. Hence, a firm should be responsible vis-à-vis the people, groups and organisations directly or indirectly linked with its operations or interested in its performance. Currently, stakeholders include entities who meet the following criteria:

- make claims regarding the firm (irrespective of their nature),

- are actually or potentially able to enforce these claims,

- want to use their influence upon the decision-making process in the firm to satisfy their claims (Adamczyk 2009, p. 49).

In the light of the above, stakeholders are: shareholders, boards of management, employees, clients, suppliers and business partners, financial institutions and creditors, the State and society (Freeman 2010, p. 32). The environment is a special, so-called silent, stakeholder.

\subsection{Areas of CSR}

We may identify many areas of corporate social responsibility. The most often invoked typology is that by Carroll (1993). His model distinguishes four levels of responsibility: economic and legal, which society demands; ethical, which it expects; and philanthropic, which it considers desired. They are all underpinned by economic responsibility. An enterprise should, first and foremost, be profit-

\footnotetext{
${ }^{11}$ The term "stakeholders" was introduced by Ansoff and Steward in the 1960s (Ansoff, Steward 1967).
} 
able or at least not incur losses. Legal liability ranks high. Firms undertake obligation to act within limits specified by the law, observe the "rules of the game", i.e., legal regulations. Examples of this type of responsibility include: protection of the natural environment and consumer rights, respecting regulations governing the employment relationship, or meeting contractual obligations. At another level, we can find moral (ethical) responsibility. It is about acting in a fair, just and proper way, exceeding the minimum standards laid down by the law. Obviously, it is relative and depends on the ethical "climate" in society but, at the same time, it is a derivative of principles applicable in the firm in question and the ethics of its managers and employees. Finally, at the top, there is philanthropic responsibility, connected with earmarking some of the firm's resources for the needs of society to offer specific assistance, improve the standard of living or solve social problems.

According to Carroll and his typology, corporate economic responsibility is elementary. Other types of responsibility are understood as auxiliary commitments. This is the so-called after profit obligation concept. Concepts of before profit obligation assume the reverse order. The moral responsibility of individual people (members of the management board, managers, employees) for ethical choices takes precedence over other areas of responsibility. Firms are obliged to consider stakeholders' expectations and treat them as equal to their objectives. Only after having met these expectations is an enterprise free to choose how it will generate profit (Kang, Wood 1999, p. 414).

In real life, however, entrepreneurs represent different attitudes with regard to corporate social responsibility. These attitudes were extensively and in detail discussed by Johnson and Scholes (1993). They identified ten categories of corporate social roles grouped in four types of organisational culture (see Table 2.1). The first type, covering categories 1-3, represents an approach, according to which corporate social responsibility is not a corporate duty and it restricts the primary function of a business, which is generating profit (Lewicka-Strzałecka 1999, p. 54). The second type (categories 4-7), takes account of the role of stakeholders in generating long-term profit. Charity or sponsoring are perceived as investments or promotion outlays. In type 8 , the firm is aware of the need to consider the needs of various stakeholders and profit is not its only objective. The last type of culture (categories 9-10) includes businesses that first of all meet social needs, where economic reality may even hamper achieving their objectives.

The above classification may be related to what Griffin proposes (Griffin 2013). He distinguishes between four types of CSR (see Fig. 2.1). The lowest level, i.e. resistance, is generated by firms which do not get involved in solving social or 
environmental problems at all, and when such problems arise they either deny responsibility or cover them up. At the second level there are enterprises which limit their CSR-related activities to what is required by law. The third level, social response, includes firms which fulfil their obligations but are unable to go beyond the binding framework. At the highest level of the "responsibility ladder", referred to as "social input", we can find enterprises active in CSR, even seeking the opportunity to make their input a social good.

Table 2.1. Categories of corporate social roles

\begin{tabular}{|c|c|c|}
\hline \multirow{2}{*}{ Firm's role } & \multicolumn{2}{|c|}{ Activities and attitude to: } \\
\hline & economy & social issues \\
\hline to achieve maximum profit & dominated by profit & $\begin{array}{c}\text { a barrier in generating } \\
\text { profit }\end{array}$ \\
\hline to achieve satisfactory profit & dominated by growth & $\begin{array}{l}\text { social expectations treated } \\
\text { as hindrances }\end{array}$ \\
\hline to defend free enterprise & $\begin{array}{l}\text { "the only business of the business } \\
\text { is business" }\end{array}$ & outside the firm's interests \\
\hline "lonely wolf" & main stress put on profit & $\begin{array}{c}\text { assumes responsibility on } \\
\text { a voluntary but unilateral } \\
\text { basis }\end{array}$ \\
\hline socially engaged & main stress put on profit & interactive links \\
\hline $\begin{array}{l}\text { to contribute to social } \\
\text { progress }\end{array}$ & main stress put on profit & interactive links \\
\hline "global actor" & main stress put on profit & interactive links \\
\hline to shape society & financially self-sufficient & $\begin{array}{l}\text { changes people's lives } \\
\text { through innovation }\end{array}$ \\
\hline to serve society & $\begin{array}{l}\text { secondary with regard to social } \\
\text { commitments }\end{array}$ & $\begin{array}{l}\text { supplies important, } \\
\text { although non-economic } \\
\text { goods and services }\end{array}$ \\
\hline to give employment & based on subsidies & supplies jobs \\
\hline
\end{tabular}

Source: Rojek-Nowosielska (2006), p. 46. 


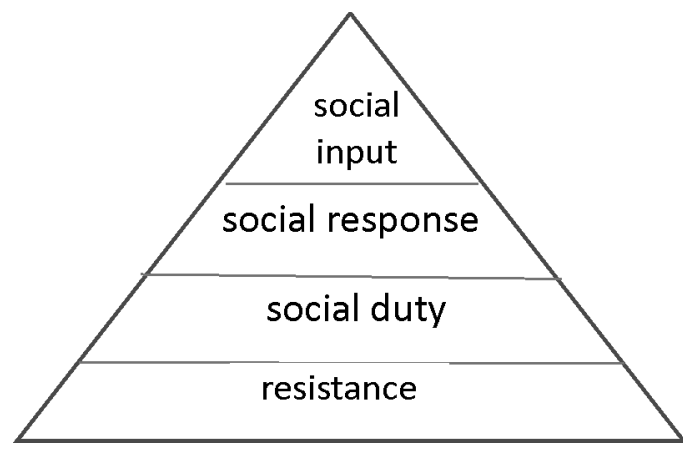

Figure 2.1. Responsibility levels according to Griffin

Source: Author's considerations based on Griffin (2013)

\subsection{CSR tools}

The list of CSR tools is long and is closely connected with the organisational corporate culture of the firm in question and its operational profile. The most often applied tools are:

- social campaigns, i.e. actions designed to change the attitudes or behaviour of a selected reference group, which use the media to convey the message;

- socially engaged marketing that takes care both of marketing goals and social needs;

- ethical programmes for employees aimed at integrating them around corporate common values;

- social reporting - preparing and drafting documents that present how a firm is managed and how responsibly it acts in business;

- corporate surveillance - a series of mechanisms used for controlling and coordinating the behaviour of various shareholders who have their own interests but collaborate with the management to effectively deliver corporate tasks;

- eco-labelling and social labelling consists in placing additional environmental or CSR-related information on product packaging or label; 
- reducing waste, pollution and the emission of greenhouse gases through the optimisation of manufacturing, transport and logistics;

- socially responsible investment, where stock exchange analysts, while analysing enterprises, consider assessment criteria for the potential of a long-term increase in the company's value based on its social and environmental performance;

- employee volunteering schemes cover activities through which firms initiate and support their staff involvement with NGOs and institutions specified in legal regulations. Employees who do voluntary work help those in need using their skills and talents while firms enable such initiatives and support them financially or in organisational terms;

- trans-sectoral cooperation undertaken by a business with NGOs and Universities which, thanks to synergy effects, helps better deliver common responsibilities.

\subsection{CSR in a corporate management system}

Each firm interacts with people, groups and organisations as well as institutions in society. Some of the relationships are purposeful and desired, some unintended and undesirable. Relationships with stakeholders are decisive for the development directions of businesses. They may support corporate goals. Their nature and frequency involve decision-making, i.e., management, which includes the following stages:

- stage one - identification of stakeholders,

- stage two - identification of stakeholders' interests and expectations,

- stage three - drafting stakeholder relationships management strategy,

- stage four - implementation of the strategy.

The above demonstrates that first we need to answer the question who our stakeholders are. In most cases we can identify:

- stakeholders who bring their capital, work and competence to the enterprise; 
- stakeholders directly involved in business relations with the enterprise in question, i.e. suppliers, clients, business partners, and competitors;

- stakeholders in the business environment, e.g. the local community, public opinion, the media, central and local government institutions, and NGOs.

Thus, an enterprise's relationships with society may be primary and secondary. They change over time and may often be conflicting. The most frequent conflicts emerge when a choice must be made between productivity and employment or output and its quality.

The second stage analyses business - stakeholder relationships. It usually starts with a map of the links between a firm and the actors whose interest should be considered when delivering the corporate strategy. Then, we identify the interest group to which the entity in question belongs. And finally we must identify stakeholder expectations. Each stakeholder engages in relationships with a business in a different way. Managers must be aware of the diverse needs of stakeholder groups and respond appropriately. However, quite often groups disregard other stakeholder interests. For example, owners are interested in achieving the highest rate of return for the capital they invested while clients want to get the highest value for money when they buy goods or services. Each group represents a different capability of using its potential to achieve intended objectives. Some, e.g. shareholders, vote and impact corporate decisions. The power of other stakeholders, e.g. clients and suppliers, comes from their ability to refuse to buy or sell. Finally, there are stakeholders who may exercise political power over a business by developing laws, filing claims or influencing state institutions to, e.g., adopt new regulations. Having identified the stakeholders and following the analysis of their needs and power, we can develop a matrix of priorities (see Table 2.2). Not all stakeholders are equally interested and engaged in each political issue.

Table 2.2. Identification of responsibilities vis-à-vis stakeholders

\begin{tabular}{|c|c|c|c|c|}
\hline Stakeholders & $\begin{array}{c}\text { Economic } \\
\text { responsibility }\end{array}$ & $\begin{array}{c}\text { Legal } \\
\text { responsibility }\end{array}$ & $\begin{array}{c}\text { Ethical } \\
\text { responsibility }\end{array}$ & $\begin{array}{c}\text { Philanthropic } \\
\text { responsibility }\end{array}$ \\
\hline $\begin{array}{c}\text { Shareholders } \\
\text { Employees } \\
\text { Suppliers } \\
\text { Media }\end{array}$ & & & & \\
Environment & & & & \\
$\ldots$. & & & & \\
$\ldots$ & & & & \\
\hline
\end{tabular}

Source: Author's considerations, based on Carroll (1993), p. 78. 
Corporate stakeholder relations are not long-lasting. Information pertaining to them must be collected and analysed systematically. The inclusion of stakeholder-related information in management is a strategic issue. Businesses may use collected knowledge to identify or modify their mission, goals, strategies or plans. It will help them predict trends developing in their environment and respond to planned undertakings. Stakeholder analysis is fundamental for business management, and stakeholder identity is reflected in the corporate strategy. Enterprises may choose one of four types of CSR strategy:

- passive - no response to social needs, just trying to neutralise issues that may potentially threaten the business. Firms that follow this strategy resist, avoid or assume no social responsibility whatsoever. They feel bound exclusively by legal requirements, which they interpret in their own favour. That is why these firms feel responsible only for the outcomes of unlawful behaviour. The overriding goal in this case is profit maximisation;

- reactive - response is given to changes in the environment and in the law. Far-reaching legalism, meaning strict adherence to law, is a typical attitude. It is also reflected in the firm's meeting its obligations regarding those stakeholder groups with whom it signed legal contracts, e.g., concerning employees. Social actions are launched in response to pressure exerted by public opinion;

- proactive - expectations coming from the environment are taken care of before any social problem arises. Enterprises which engage in solving problems thoroughly analyse the stakeholders, their expectations and types of power, and try to balance the conflicting interests of individual groups. The strategy consists in shaping positive stakeholder relations based not only on legal obligations but also on ethical norms;

- interactive - active engagement in delivering social goals. Enterprises include all stakeholders in the management system. Together with social partners they seek ways to solve or prevent social problems. Firms actively look to find their place in society by undertaking a vast range of activities.

When incorporating CSR principles into business management, firms may avail themselves of ready-made standards. One of them is the AA1000 standard, developed in 1999 by the Institute of Social and Ethical Accountability, which introduces social and ethical issues into the strategic management of an organisation and its operations. 
The standard includes 5 main stages:

1. Planning - the organisation commits to the process,

2. Accounting - the principles of social responsibility are identified,

3. A social audit is conducted and a CSR report prepared,

4. Embedding - the process is strengthened,

5. Stakeholder engagement with groups linked to the organisation.

The standard may be used not only for strategic analysis, but also in the internal assessment of an organisation when it comes to social and ethical accountability and for self-improvement purposes.

\subsection{CSR principles}

The CSR concept would be incomplete if we did not discuss the principles to be followed by a socially responsible organisation. These principles have been formally adopted at international level. We should mention here the principles setting forth the norms of acceptable business behaviour approved by the Caux Round Table ${ }^{12}$, the Global Sullivan Principles ${ }^{13}$ or the Global Compact ${ }^{14}$ guidelines. They provide useful guidelines for companies on how to use and apply CSR. Since nowadays Global Compact is the major global initiative in the area of corporate responsibility, having already been joined by more than 12,000 participants, including 8,000 businesses from 145 countries, we shall focus on its principles.

\section{Human rights:}

- support and respect human rights proclaimed by the international community,

- the elimination of all cases of human rights violations by businesses,

\footnotetext{
${ }^{12}$ An international network of experienced business leaders from Europe, Japan and the United States, established in 1986 to mitigate tensions in the business community.

${ }^{13}$ Declared by Sullivan in 1977 in connection with combating apartheid in South Africa. In 1999 they were announced by the UN.

${ }^{14}$ Global Compact was launched in 1999 on the initiative of Kofi Annan. It is a platform for dialogue and education voluntarily joined by businesses. It is a forum for the exchange of knowledge and expertise as well as the promotion of corporate social responsibility.
} 


\section{Labour standards:}

- respect freedom of association, elimination of all forms of forced and compulsory labour,

- abolition of child labour,

- effectively counteracting discrimination in employment,

\section{Environment:}

- a precautionary approach to the environment,

- undertake initiatives to promote environmental responsibility,

- the application and promotion of environmentally friendly technologies,

\section{Anti-Corruption:}

- working against corruption in all its forms, including extortion and bribery.

The first two Global Compact principles originate from the Universal Declaration of Human Rights adopted by the UN in 1948. Traditionally, human rights have fallen within the remit of states and governments, and international law in this area has been developed and addressed to them, however, there is a growing population of businesses which (motivated by a variety of legal, moral or business factors) realise the need to face the issues of human rights. Four principles of the Global Compact relating to labour standards come from the International Labour Organisation Declaration on Fundamental Principles and Rights at Work of 1998. The Declaration is the effect of the annual International Labour Conferences, tripartite meetings of representatives of governments, employers and employees from 177 countries. Three further principles relating to the environment are founded on the Rio Declaration on the Environment and Development. Supplementing the two major environmental principles, Global Compact focuses on two major challenges of our times: climate change and sustainable water management. The last of the ten principles was declared relatively recently, i.e., in 2004. Corruption and fighting corruption are among the top challenges of the modern world. Corruption adversely affects societies but is also extremely costly to business. In many parts of the world, it accounts for over $10 \%$ of the cost of business and the value of the "bribery industry" is estimated at one trillion USD"

CSR is implemented through the voluntary obligations of firms as well as, increasingly often, based on standards and formal and legal commitments. Most

${ }^{15}$ https://www.unglobalcompact.org (access: 25.09.2015). 
often, they relate to the issue of transparency and mandatory reporting of non-financial data by enterprises. They are enacted by stock exchanges, national governments and international organisations.

In the European Union (EU), CSR policy was delineated by the White Paper published by the European Commission in 2002. It covers four EU activity areas:

- education, exchange of experience and good practices: research on the impact of CSR upon business and society, the exchange of experience and good practices among enterprises and Member States, the development of adequate managerial skills, the adaptation of social responsibility principles to suit the SME sector;

- developing corporate social responsibility tools: codes of conduct, management standards, auditing and reporting rules, product labelling and socially responsible investment;

- launching a Multi-Stakeholder Forum on CSR;

- integrating CSR in all EU policies.

The document is addressed to EU institutions, Member States, social partners, business and consumer associations, and enterprises.

CSR has also been standardised internationally. An example is the ISO 26000 standard developed by the International Organisation for Standardisation in 2010 to provide guidance on principles of social and environmental responsibility in the following fields:

- organisational governance,

- human rights,

- labour practices,

- the environment,

- fair operating practices,

- consumer issues,

- community involvement and development.

ISO 26000 standard is intended to be useful to all types of organisations: business, central and local administration and the third sector. It is not subject to certification but is a collection of voluntary practices and standards. 


\subsection{CSR: pros and cons}

Advocates of corporate social responsibility point to the fact that the market does not regulate the economy to a sufficient extent. Due to the failures of the "invisible hand of the market" mechanism, the economy needs the "visible hand" of the government, NGOs and business. When a firm gets involved in socially responsible actions it escapes government regulations in this area. The latter are costly and reduce the flexibility in making business decisions, hence, from a business point of view, it is better to take initiative in social matters and retain more freedom in economic operations. Thus, assuming social responsibility provides an enterprise with an opportunity to restrict the regulatory functions of the state.

Whether businesses like it or not, they must adapt to the needs of society, which requires enterprises to operate in a particular way and may demand the liquidation of environmental damage resulting from economic operations. Enterprises exert substantial impact upon the environment and they benefit from the resources entrusted to them by society, e.g., access to natural resources. No wonder that, in accordance with the principle of stewardship, they make commitments to operate in a socially acceptable way or, at least, be accountable for the effects of their actions. If a firm uses natural resources or pollutes the environment, it should take part in environmental protection.

Moreover, social engagement may be consistent with the firm's own interest. If society expects business to take care of social issues, undertaking such actions and positively promoting them lie in the business' best interest. As a result, a socially responsible business will be respected, which usually increases client interest, sales, and gives better access to capital and skilled labour. The improved image of a business, its more positive assessment and approval in stakeholders' eyes, cannot be achieved overnight. Benefits of CSR, more broadly explored in the next section, materialise over a longer time frame. However, many researchers have no doubt that they exceed the cost of socially-friendly actions. We may conclude by saying that the ethical conduct of an enterprise is a profitable investment.

And finally, CSR supporters are also of the opinion that modern businesses, in particular multinational corporations, have huge resources often exceeding the potential of some national economies. These resources should be deployed in solving or mitigating existing social problems.

In the era of liberalisation and globalisation, business plays an increasingly culture-shaping role. In the face of the crisis of values, the values promoted by entrepreneurs, such as efficiency, profitability, productivity, capacity and material- 
ism, have gained in importance. Hence the responsibility for values and attitudes proclaimed and created by enterprises. Noteworthy, over a longer perspective, a business will take advantage of its culture shaping conduct, as its stakeholders, employees, clients and suppliers, will be the "promoters" of these values. We can see it clearly on the example of the enterprise-employee relationship. When an enterprise limits its engagement in solving social issues, it stresses profit generation related goals and it is walking a fine line between legal and illegal in moral ambiguity, which may surely negatively affect the attitudes of its employees and their commitment to issues vital to the enterprise.

CSR has also got its opponents. Their argument is that "the social responsibility of business is to increase its profits"16. Firms are stricte economic entities and they may not be motivated by ethical reasons. On top of that, imposing social obligations upon entrepreneurs may divert their attention from the primary task of profit maximisation. Expenditure on social actions impoverishes also and in international markets, regarding competitors not involved in such activities. Firms may also hide the costs of their social engagement in higher prices of goods and services meaning they will ultimately be paid by society. From the above perspective, would not it be better - CSR opponents ask - if stakeholders themselves earmarked a portion of their income for social or environmental purposes? Quite possibly, if the public knew the real costs of CSR and who bears them, perhaps it would not demand socially responsible actions.

Businessmen and managers may be unaware of what specific social problems they should tackle, what strategies they should put in place, and what concrete steps they should instigate. Market, not politics, is their domain, and markets provide too little information on social matters. Social issues should be decided by governments or specialised institutions. Hence, entrepreneurs' decisions are arbitrary and often mistaken, not only because they are made by incompetent people, but also because they are often "contaminated" with the desire for profit.

Besides, managers as plenipotentiaries of business owners are employed to manage production and maximise profit, not to offer eleemosynary services. Individual proprietors are in a different position. If they decide to reduce the income to meet their social obligations, unlike managers they spend their own, not somebody else's money. When the management board reduces the financial surplus that should be paid to shareholders to earmark it for social goals, de facto the business behaves like a thief who steals and distributes profit.

${ }_{16}$ Title of the article of Friedman, one of the most fiercest critics of CRS (Friedman 1970). 
Another argument against burdening enterprises with social obligations is that social engagement substantially increases the power and influence of a business while even without it, business exerts huge impact upon society nowadays.

Finally, there are some who believe that the mission of a business consists in manufacturing useful goods and services, which exhausts its social role (Kaczocha 2009, pp. 22-33).

\subsection{The CSR impact upon business}

In a modern economy, social engagement largely influences business development. Today's enterprises need not only raw materials, capital, equipment, labour and knowledge, but they also depend on social approval (Hatch 2002, p. 96). The increased relevance of intangible resources for building a competitive advantage, and the specificity thereof, have given the CSR doctrine a new place in business management. It is no longer identified with philanthropy, unrelated to economic efficiency, it has become a tool to improve profitability (Paliwoda-Matiolańska 2009, p. 169). Studies have shown that businesses taking up the challenge of corporate social responsibility win loyal clients, enjoy public trust and build up their reputation. This way, they may win a competitive edge, which in the longer term translates into concrete financial performance.

By implementing the CSR system, firms develop intangible, innovative resources, often irreplaceable or inimitable, which give it a lasting competitive advantage. Such resources include:

- social capital,

- innovation,

- reputation,

- entrepreneurial environment.

Social capital is the collective value of social organisation factors, such as trust, norms, and networks which may improve the efficiency of society through coordinated actions (1993). Social capital adds to the creation of value at all levels of business. It is of huge importance for relationships between firms and employees. It helps to attract good employees who are educated, open, loyal and responsible, and who are willing to share knowledge and improve, create, and innovate. Social capital also positively impacts the corporate organisational climate (Bem-Kozief 
2008, pp. 112-116) and translates into stable employment based on strong identification with the enterprise. Social capital positively impacts relationships with suppliers as well as the stability and efficiency of distribution channels.

Similarly, by means of their business strategy, firms develop an entrepreneurial culture, understood as "convictions, attitudes, assessment of business operations and how they are conducted" (Paliwoda-Matiolańska 2009, p. 190). This may come through in many fields, e.g., by the use of renewable resources, strategy to export only highly processed goods, relationships with shareholders or the policy to attract external resources.

The environment of a modern enterprise expects it to apply innovative solutions: new products and services but also innovative engagement in solving globally acknowledged economic, social and environmental issues, such as climate change, increasing poverty and social inequalities. That is why, today, the main success factor for a firm is the identification of stakeholders' needs and expectations, and the development of new products, services, technologies and strategies that address them.

Reputation is the image of business in stakeholders' eyes. We mean here both the firm's visibility and its credibility. According to several studies, the positive and coherent assessment of the external environment is a tool of business growth and economic security which also provides a sort of shield in moments of crisis. Business reputation has two dimensions: a general one, connected with the transparency of operations, meeting its commitments, honesty, accountability vis-à-vis society and the environment, and the dimension directly related to the firm's products or services and the quality thereof.

Thus, we can see that by implementing the CSR system, an organisation may benefit greatly. Benefits should be perceived in a long-term perspective. They are:

- increased investor interest - Creditors are much more interested in working with responsible businesses, which, besides good financial performance, may offer a transparent management system, and responsibly build their image and good relations with those around them the environment. To many investors, financial credibility depends on the social credibility of a business;

\section{CSR and financial performance}

Numerous studies have been conducted on the links between CSR and the financial performance of firms. CSR positively impacts the cost of capital. Studies have shown that the market perceives socially engaged firms as posing a smaller risk than others 
and rewards them with better rating. There is a convincing body of evidence that good management in the area of CSR positively correlates with the financial performance of a business. It is true of the results reflected in books of accounts and in the value of shares. Firms from the top of the CSR rankings achieve above-average financial results and the value of their shares remains above market indices. The effects can be noticed in medium and long-term perspectives.

Source: Grzymisławski (2013)

- stronger customer and stakeholder loyalty - Consumers with increased social awareness are guided in their choices by trust with a business and its image. A growing portion of consumers pay attention to how "organic" a product or service is, whether social responsibility principles have been observed in its production and to the overall reputation of a business;

- better relationships with local community and authorities - Taking part in the life of the local community, undertaking long-term and tangible social investments, facilitates effective and smooth business operations. Social responsibility helps a firm become embedded in the community, become popular with local inhabitants and win the trust of local authorities. A special role is played by the cooperation with NGOs and building trans-sectoral partnerships;

- improved competitiveness - The implementation of CSR principles is an asset giving firms a competitive advantage. To Polish businesses, a transparent CSR policy may be a way of building their positions in international markets where expectations connected with meeting CSR standards are more obvious;

- improved corporate organisational culture - By taking up CSR challenges, a business improves standards governing its conduct regarding stakeholders (employees, business partners, clients) thus avoiding the cost of "bad partnership". These changes, based on trust, responsibility and transparency for all stakeholders, shape the corporate organisational culture;

- shaping positive image among employees - Corporate social responsibility is among the non-financial elements of staff motivation. Codes of conduct, social programmes, and taking care of the environment improve the firm's image in the eyes of its employees. Employees have more respect for what the firm is doing when they see that it addresses social problems vital also for them; 
- attracting and retaining the best people - The improved image of a business increases employees' trust and makes it more attractive in the labour market, which attracts new employees and helps to retain the best ones;

- tax benefits - Social expenditure may reduce taxable base.

Social benefits include:

- giving visibility to the problem and engaging bigger social groups and the government in the delivery of social goals,

- education of society,

- better shape of the natural environment,

- developing a philanthropic mindset,

- stimulating the economic and social development of the location, region and even the country (Ratajczak, Stawicka 2008, p. 135).

\subsection{CSR in practice}

Businesses are more and more aware of benefits resulting from sticking to CSR principles. Polish entrepreneurs believe that business operations modelled in line with CSR positively impact their financial performance. In the study conducted by KPMG, an improved image of the firm in the market was the most often selected benefit - with over a half $(52 \%)$ of respondents attributing it to CSR-related activities. Another advantage of conduct compliant with corporate social responsibility principles is the potentially stronger approval of the business environment selected by over a third of the interviewed entrepreneurs (KPMG 2015).

Almost half of the overall business population in Poland is involved in CSR activities. Further, $15 \%$ consider launching them, meaning we may expect that the idea will develop in Polish businesses in the years to come. This is true, however, mainly of large and medium-sized enterprises, especially with the involvement of foreign capital.

Businesses active in the field of CSR most often decide to support local communities (89\%) and engage with the natural environment (85\%). These are the two most important areas which featured in respondents' opinions as the most 
important for their business operations. Below we present some examples of CSR practices $^{17}$ :

- In the autumn of 2014, acting within the framework of the Project "The Greenest Terminal in Poland", DB Schenker opened a new cross-docking terminal in Złotoria near Białystok, the most environmentally-friendly one in Poland. The terminal is equipped with LED and solar lamps, which enable them to reduce $\mathrm{CO}_{2}$ emissions by 31,400 tons annually. Solar thermal collectors on the roof of the office heat utility water. The terminal also stores over 7,000 litres of rainwater, reducing water consumption. The building design ensures optimization of daylight, good acoustics and adequate quality of air. There are heating and ventilating devices in the hall installed to recover heat, and a condensation furnace.

- "Forest full of Energy" is an original environmentally-friendly campaign of the energy distribution company PGE, delivered in cooperation with the Regional Directorates of State Forests. The project is designed to promote an environmentally-friendly attitude among children and youngsters and is addressed primarily to local communities. The event was attended by ca. 700 people who planted over 40,000 trees. The same company organised another campaign "Holidays against the Current - Discovering Energetic Places". It presented attractive tourist destinations in territories earlier occupied by PGE for business purposes.

- Under the "Huge Waste Collection" campaign, IKEA encourages its clients to bring waste for disposal. In return, the company offers seedlings of various plants.

- Kronopol launched a project "Actively through Green Forest", within which a cycling and walking route was regenerated, and fitness equipment (the so-called outdoor gym) was placed in one of the favourite leisure locations in Żary. The company also supplied 9 schools in the county of Żary with bakery products once a week. They distributed 120,000 buns.

- PGNiG TERMIKA within the campaign "Back to School" purchased school kits for pupils from schools in the vicinity of their power stations.

- Within the framework of the "Sustainability Ambassador" programme, volunteers from Henkel visited schools to speak about the need to care for the environment, the sustainable development idea and responsible consumption, to more than 800 pupils.

${ }^{17}$ Examples taken from: Responsible Business Forum (2015). 
$60 \%$ of firms implement good practices in the area of health and safety at work, dialogue with employees, recruitment, training or employee volunteering programmes. Some examples are presented below:

- The NEUCA company, which employs over 4,000 people, many of them parents, launched "My Mamy" [We Mothers] programme. It includes a series of opportunities for future parents starting from the period of pregnancy, such as subsidies for childbirth classes, flexible working hours (agreed with the superiors), participation in medical and preventive consultancy and events, discounts in partner businesses, and refunded LUX-MED medical services. When a child is born, the parents are entitled to a newborn kit, subsidies for nursery and kindergarten, medical care for the parent until the child is 3 years old, an extra day off (paid) on the child's birthday (until he/she is 11), school kits for pupils and Christmas gifts. Parents who come back to work receive a welcome kit (reimbursement of care treatments), a possibility to work flexible hours, and to rent equipment to work at home.

- The mBank Group employs over 6,000 people. It is not always possible to reach those whose commitment and professionalism are exceptional. The bank decided to find them and developed a programme "People Make Us Stand out - Help Us Find the Outstanding Ones". It motivates employees to undertake new challenges and get involved in innovative ventures.

- At Christmas time, the employees of PKN ORLEN take part in their employee volunteering programme "Making Dreams Come True". It consists in fulfilling the wishes of children from orphanages. In 2014, the initiative was handed over to employees for the first time. They identified orphanages and care centres to be targeted by the programme. In total, more than 700 employees made the dreams of children from 16 orphanages come true.

- Tesco supports its employees' families, in particular multi-child ones. Educational scholarships of the Tesco Foundation for Children "Wise Start", worth PLN 1,500 each, were awarded to 116 children in the first edition of the programme. On the occasion of Christmas, all children from low income families received a $100 \mathrm{PLN}$ gift card. The programme covers almost $800 \mathrm{Te}-$ sco employees (2,400 children) and its total amount exceeded PLN 240,000.

- In KGHM, employees' social activities focus around the volunteering programme "Copper Heart". One of its most organisationally advanced projects is that of the KGHM Bone Marrow Team. For years the team has been promoting the fight against leukaemia and registers bone marrow donors. Volunteers have registered over one thousand potential donors. Three of 
them have donated bone marrow and saved lives. Besides fighting leukaemia, volunteers propose other initiatives. To date they have, e.g. painted doghouses in a dog shelter, organised charity concert and art workshops for children from orphanages and cleaned up Kunickie Lake. They also conducted several workshops in physics and chemistry for teenagers.

- The underperforming state pension system, the wish to ensure financial security to its employees in the future and to make them aware that they need to save regularly were reasons why Volkswagen Poznan launched its Employee Pension Scheme. The scheme could be joined by all employees who had spent at least 2 years in the company. In 2014, the participation rate was $88 \%$ and $26 \%$ of employees decided to pay additional premiums. Every year, the company reminds its workers about the benefits of the scheme, encourages them to join it, and informs those who leave the company about what they can do with their accumulated assets. For Volkswagen Motor Polska, prevention means also the habit of taking care of one's health and changing the lifestyle. That is why, every two years, the company offers a free-of-charge medical examination during working hours as a part of the programme "Healthy Woman, Healthy Man". The objective is to detect early lifestyle diseases, such as diabetes, heart disease or cancer. An employee diagnosed with any disease may benefit from a medical package paid by the employer in case of serious diseases or use specialist medical consultancy services. On top of that, there is a special social benefit fund which may be used to finance costly treatment, surgery or specialist examination. Ca. $70 \%$ of employees benefit from periodical examinations.

Why do some businesses not get involved in CSR projects? Maybe they are not familiar with the CSR idea, they do not have enough knowledge or they lack staff qualified to take care of the subject. Many firms do not see tangible benefits of socially engaged actions and some do not have enough financial resources.

\section{Questions and assignments}

1. What is your understanding of corporate social responsibility? How, in your opinion, does corporate social engagement differ from Public Relations?

2. What benefits do socially engaged activities bring to business?

3. In your opinion, should businesses engage in social issues?

4. List the major stakeholders of an enterprise and explain their relationships with it. 


\section{Literature}

Adamczyk J. (2009), Społeczna odpowiedzialność przedsiębiorstw, PWE, Warsaw.

Ansoff H.I., Stewards J.M. (1967), Strategies for a Technology-Based Business, "Harvard Business Review", vol. 45.

Bem-Koziel K. (2008), CSR a efektywność pracy, [in:] Społeczna odpowiedzialność biznesu w małych i średnich przedsiębiorstwach, M. Bąk, P. Kulawczuk (eds.), Instytut Badań nad Demokracją i Przedsiębiorstwem Prywatnym, Warsaw.

Davis K., Blomstrom R. (1966), Business and its Environment, McGrower Hill, New York.

Davis K., Blomstrom R. (1975), Business and Society: Environment and Responsibility, McGrower Hill, New York.

FOB (2015), Odpowiedzialny biznes w Polsce w 2014. Dobre praktyki, Warsaw.

Freeman R.E. (2010), Strategic Management. A Stakeholders' Approach, Cambridge Univeristy Press, Cambridge.

Friedman M. (1970), The Social Responsibility of Business is to Increase its Profits, "The New York Times Magazine", September 13 available on http://www.colorado.edu/ studentgroups/libertarians/issues/friedman-soc-resp-business.html (20.10.2015).

Griffin R.W. (2013), Podstawy zarzq̨dzania organizacjami, PWN, Warsaw.

Hatch, M.J., 2002, Teoria organizacji, PWN, Warsaw.

Johnson G., Scholes K. (2008), Exploring Corporate Strategy, Prentice Hall, London.

Kaczocha W. (2009), Filozoficzno-etyczne rozwinięcie idei społecznej odpowiedzialności biznesu, [in:] Społeczna odpowiedzialność biznesu. Uwarunkowania, kontrowersje, dobre i złe praktyki, Z. Pisz, M. Rojek-Nowosielska (eds.), "Prace Naukowe Uniwersytetu Ekonomicznego we Wrocławiu", no. 42, University of Economics, Wroclaw.

Klimczak B. (1996), Etyka gospodarcza, University of Economics, Wroclaw.

KPMG (2015), Społeczna odpowiedzialność firm. Fakty a opinie, Warsaw.

Lewicka-Strzałecka A. (1999), Etyczne standardy firm i pracowników, IFiS PAN, Warsaw.

Paliwoda-Matiolańska A. (2009), Odpowiedzialność społeczna jako źródło przewagi konkurencyjnej, [in:] Społeczna odpowiedzialność biznesu. Uwarunkowania, kontrowersje, dobre i złe praktyki, Z. Pisz, M. Rojek-Nowosielska (eds.), "Prace Naukowe Uniwersytetu Ekonomicznego we Wrocławiu", no. 42, University of Economics, Wroclaw.

Ratajczak M., Stawicka E. (2008), Społeczna odpowiedzialność biznesu jako narzędzie podnoszenia konkurencyjności sektora MSP, [in:] Społeczna odpowiedzialność biznesu w małych i średnich przedsiębiorstwach, M. Bąk, P. Kulawczuk (eds.), Instytut Badań nad Demokracją i Przedsiębiorstwem Prywatnym, Warsaw.

Rojek-Nowosielska M. (2006), Kształtowanie społecznej odpowiedzialności przedsiębiorstw, University of Economics, Wroclaw.

Rybak M. (2004), Etyka menedżera - społeczna odpowiedzialność przedsiębiorstwa, PWN, Warsaw. 
Considering environmental protection requirements in business operations may, in the long run, determine if a lasting comparative advantage can be achieved. That is why our textbook, rich in case studies, identifies not only the threats a business may pose to the environment but stresses the ways of reducing its negative impact. It discusses, among other things, the concept of corporate social responsibility, environmental management systems, methods and the importance of eco-labelling goods and the so called green public procurement in the private and public sectors. The book is addressed primarily to students of courses in economics and management. We hope it will also make interesting reading for entrepreneurs, representatives of business environment organisations and the staff of public administration at different levels.

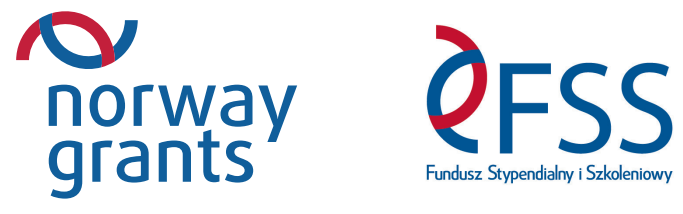

Project: The creation of new interdisciplinary curricula in the field of economics of environmental protection (in Polish and English) at the University of Łódź. Project supported by a grant from Norway through the Norway Grants and co-financed by the Polish funds.

The aim of the project is to improve the knowledge and awareness of Polish and foreign students, the faculty and alumni of the University of Łódź in the fields of sustainable development, ecology, international business and finance.

Grant amount: 533083 PLN 